\title{
THE CANADIAN DOCUMENTARY DRAMA: TRAJECTORY OF ITS GROWTH AND SALIENT FEATURES
}

\author{
Mr. Nanavati Devang Sanatkumar
}

\section{ABSTRACT}

The Canadian documentary drama is a unique genre of dramatic art in terms of its conceptual growth, its objectives marked by post-colonial hues and its insistence to explore truth of a given issue holistically. The present paper attempts to discuss as to how a Canadian docudrama differs from the other dramatic genres like history play, problem play or commitment play- in spite of the fact that it certainly weaves into its structure historical data, discusses contemporary social problems and exposes the politics of socio-economic and racial colonization.

Although this region-specific dramatic art had become remarkably popular in Canada in 1970s and 1980s, its artistic potential certainly transcends spatiotemporal boundaries because it has the capacity to de-colonize any community by interrogating and undermining the hypocrisy of its existing myths of human progress. Hence, while tracing the development of this stage art, this paper also aims to discuss various features of this art form.

Key words: Canadian Docudrama, De-colonizing the Canadian stage and social psyche, Alienation Effect, Subversion of Myths of Progress, Environmental Theatre.

The term "documentary play", according to the Oxford Companion to Theatre, had first been applied in the 1950s to a kind of play which appropriates some of the journalistic techniques like those of the American "Living Newspaper" (270). The latter had been a form of stage production established by Hallie Flanagan in 1930s in America for social education. Flanagan had extended the theatrical expressions pioneered in 1920s in Germany by Erwin Piscator. 
Through the re-presentations of the factual data of the specific historical issues, Piscator sought a theatrical style that enabled artists to forcefully re-define the conventional constructs about certain politico-cultural realities of a particular community.

Although, similar style of expression could also be noticed in the Canadian longer poems written during and after 1930s, and although such documentary trends were also introduced in the Canadian films by Grierson in 1940s, the documentary mode of expression was not appropriated much on the Canadian stage till the 1970s, which was rather a late phenomenon, compared to the growth of this genre in the dramatic literatures of Germany and America.

What prolonged the advent of the form of docudrama in Canada can be understood in light of the politico-cultural history of the English-Canada from the soil of which the form of the Canadian docudrama fully developed during the 1970s.

Canada had remained a British colony for more than a century and was granted confederate status in 1867 with the introduction of the British North America Act that initiated the political merger of the different provinces of Canada. This political consolidation of all provinces could materialize fully only in 1949 when Newfoundland joined the Confederation at last.

Considered as British subjects till 1947, the people of Canada had not been able to develop among them either unanimously cherished ideals/dreams or any sense of nationalistic feelings, which are prerequisites for any community to develop a literary convention of its own. Moreover, the composite form of drama can be based only on a certain, recognizable literary tradition- which Canada could not evolve till the mid twentieth century on account its long colonial experience.

Besides its belated political birth, there were several other hurdles for Canada that also checked the growth of a particular literary tradition till the later part of the twentieth century. Some of them were: The scarce population of the culturally and 
ethnically diversified immigrants, their sporicidal existence on the world's second largest continent and their initial hardships in struggling to settle down amid an inhospitable climate on an alien land. These obstacles allowed the Canadian artists little scope to formulate any specific literary "tradition" from which their "individual talents" could have drawn to create a play, to use T.S. Eliot's phrases.

Although Canada had no palpable literary convention till the end of the twentieth century, thinking of the ancient ritual dramatic performances of the Indians, Mavore Moore argues that the Canadian theatre is not a recent phenomenon (qtd. in Perkyns. Introduction. Major Plays 2). Moore's claim seems hardly tenable because assimilation of the Native playwrights like Thomson Highway into the main stream Canadian dramatic literature is itself a fresh episode of the 1980s. Moreover, one has to include the playwrights other than the Native while discussing the Canadian theatre, which needs to be understood in a broader context. Perhaps that is why C.R. Visweswara also notices unavailability of any "significant drama which was intrinsically Canadian" in the Canadian literature before the twentieth century ("Canadian Drama" 126).

Due to the absence of any noticeable repertoire of Canadian plays between the 1880s and the first world war, as Perkyns notes, the British and American travelling troupes enjoyed hay days in Canada (Introduction. Major Plays. 3-4). Those foreign importations dominated the English Canadian stage till 1920s by offering nostalgic satisfaction to the spectators who had been inclined to watch the British/American classics since their geographical location in Canada had made their emotional affiliations with their original roots perhaps even stronger. Their love for the foreign plays made them generate a lukewarm response towards any play that might have contained local themes. Therefore, till the end of the nineteenth century, on account of the long colonial experience of the Canadians and the influence of the American cultural hegemony, Canadians continued to inferiorize their original works.

Consequently, Canadian artists had to turn towards their neighboring country which had an already established dramatic tradition by then. As a result, as J.L. Granatstein notes, till the beginning of the twentieth century, Canada had hardly 
any theatre which could be called "Canadian" in any way (5). Nevertheless, in the middle of the twentieth century that scene gradually changed when the political merger of the Canadian provinces began to influence the process of the formation of something like a Canadian culture.

In 1940s, a wave of awareness began to emerge among the social and political circles of Canada about the need to encourage originality in Canadian playswhich reflected that now the Canadians, in spite of their cultural diversities, started dreaming of establishing a distinctive identity of their own; now they wanted to identify with the soil they inhabited for a considerable time span.

In response to the newly emerging cultural craving for self-assertion, the Canadian government decided to promote theatrical activities in Canada and various play contests and programs such as the Alberta Drama Festival, Challenge Trophy, Worker's Experimental Theatre and the Dominion Drama Festival were arranged which activated different playgroups of the Canadian regions. The Canadian Broadcasting Corporation also encouraged native talents by telecasting productions having Canadian themes and appeal.

Founded in 1934, Herman Voaden's workshop, as exemplified in his Hill Land, showed the first signs of the growth of originality in the Canadian productions. Voaden's Symphonic Expressionism indicated that the Canadian artists were being equipped to expand their literary borders to cope with the contemporary, international dramatic trends.

Following the Massey Commission's recommendations, the Canada Council began to offer subsidies from 1957 to the regional play groups and experimental theatres like Theatre Passee Muraille came into being which, according to Don Rubin, staged 200 plays between 1970 and 73 out of which $90 \%$ were Canadian in content (330). It was the time when, as John Coulter also notes, the Canadian playwrights, who were determined to shake off Americanism from the Canadian stage, began to discover for their plays "inviting subject matter" in the Canadian "Prairie droughts," "crop failure," "mining disasters" and in the "poverty of the slumdwellers, city streets or country shacks" (qtd. in Perkyns. Introduction. Major Plays 9). 
As if to substantiate Pollock's and Coulter's views, came up the Centennial Year of 1967 celebrations when the Canadian stage witnessed successful performances of George Ryga's Ecstacy of Rita Joe and John Coulter's Riel which, for the first time, highlighted the previously - neglected and basically Canadian issues relating to the historical maltreatment of the ethnic groups of Canada. These plays received warm welcome from the Canadian masses since, by documenting the subtle politics of the white Canadians that had engendered racial discrimination in Canada, they also articulated an analogous, pent-up Canadian problematic of the politico/cultural subjugation of Canada by the colonial/expansionist approaches of the British/American governments.

During the decade that followed the Centennial Year, the documentary plays that vocalized such kinds of Canadian problems continued to be appreciated. In an article "George Luscombe and the Theatre of Cabotin" Neil Carson accounts for the vogue of the documentary works that prevailed in English Canada during the 1970s thus:

The most successful drama of the seventies was that which reflected the audience's own experiences on stage and the great popularity of docudrama and Collective creations during the period attests to this wide spread hunger for recognition and identification. (156)

Following the demands of the Canadian masses, the documentarians of the $70 \mathrm{~s}$ such as Sharon Pollock, James Reaney, John Coutler, Rick Salutin, Cris Brooks and others appropriated this popular form of drama in different ways.

According to Diane Bessai, these dramatists utilized the documentary modes "either as political critique of official or media versions of crucial issues of the day," or as "...people's theatre speaking in the voice of its own community" ("Documentary into Drama" 192). The latter kind of documentaries is what Neil Carson refers above to as Collective Creations. The Donnellys, Blood Relations, Riel, Public Lies or Komagata Maru Incident could be placed in the first category mentioned by Bessai since these plays criticize the "official/media" versions of the issues they deal with, whereas Chris Brookes' Buchans and Rex Deverells 
Medicare! are collective works that needed people's participation at every stage of its creative process.

Both kinds of docudramas mentioned above, in spite of their differences in forms, types of issues, or length of performances, share some common features on the basis of which the term "Canadian documentary drama' can be defined. Otherwise, it becomes difficult to circumscribe the nomenclature in general terms, because as Bill Nichol says:

Documentary as a concept or practice occupies no fixed territory. It mobilizes no finite inventory of techniques, addresses no set number of issues and adopts no completely known taxonomy of forms, styles or modes. The term documentary must itself be constructed in much the same manner as the world we know and share. (qtd. in Dickinson 106)

Although Nichol's explanation of the term liberates the dramatic form of documentary expression from any definite boundaries, considering the common characteristics of the Canadian plays under discussion the term 'documentary play' I venture to define this term as : A Canadian documentary drama that appropriates the experimental/conventional dramatic devices is an artistic attempt of re-defining the socio-political Canadian realities in light of the documentary details pertaining to the specific issues chosen from the past.

Canadian docudramas sound similar in their common intention of detecting the Canadian realities by scrutinizing the local histories. For the exposition of different perspectives on the controversial Canadian issues, the playwrights share some common theatrical techniques they have inherited from their German and American forerunners. In fact, it is the instance of using the factual information of the subjects dramatized and the resulting theatricalizm which effectively link the Canadian documentary experiments that otherwise vary remarkably in their forms and the locations of the issues. Due to such a significance of theatricalizm on the documentary stage, Cuddon has defined 'documentary experiment' as: 
A form of drama, related to epic theatre which is propagandist and dialectic and may make use of relatively recent history and documentary evidence of the kind provided by newspapers, reports, archives, official histories, diaries and journals. (199)

Cuddon's definition with its evident emphasis on the technicalities of the form of docudrama becomes useful in understanding the genre of Canadian docudrama because it opens up the important questions regarding the causes/consequences of the choice of historical topics in docudramas. It also raises the issues of the Canadian obsession of seeking the truth that stimulated the issues dramatized, and the relation of the Canadian documentary experiments with the "Epic theatre" which Cuddon refers to in the aforesaid definition.

Inclusion of historical matter in their plays was quite natural for the Canadian playwrights because, as discussed earlier, in 1970s when the Canadian playwrights became concerned with the problems of decolonizing the Canadian stage, they had to turn towards their own past. For discovering the local issues when they began to explore their history, they became acutely conscious about the urgency to develop an adequate self-perception for the Canadians.

During their research work into the history of their nation they felt they needed to dramatically conduct an impartial re-assessment of the Canadian politico-cultural realities which, according to them, had been often misrepresented by the monolithic colonial vision. In a country where preservation of multiculturalism has been guaranteed in its constitution, they thought, it was necessary for them to establish a new social/artistic practice of validating a pluralistic approach towards evaluating any historical controversy. As if responding to the twentieth century European scientific, religious, emotional and intellectual metamorphosis that subverted the previous definitions of 'the final truths' in all spheres of life, the Canadian docudramatists also decided to view any pre-existing truth in its totality.

In a Gujarati article "Vatayan," Chandrakant Baxi rightly stresses the need to remain aware about the limitations of the human mind which often mistakes illusions for realities. He writes that our "normal" eyes perceive the earth as a 
stationary object, which is contrary to the scientific fact. Therefore, he urges an educated man to explore all the probable realities pertaining to a given issue in order to comprehend its truth in holistic terms.

Canadian documentarians are also concerned about training their spectators to consider the issues being dramatized from all possible angles. To achieve this goal, they often adopt the techniques of the 'epic theatre' of Betolt Bretcht, who utilized theatre as a device to educate his audience to let them develop a critical approach towards the re-presentation of any historical episode. Along with the use of anti-illusory techniques of Bretcht, the Canadian playwrights/directors have also extended various artistic methods that had been manipulated much before them by the Canadian writers of the long narrative poems, who had also cherished the idea of re-discovering new myths for Canada.

As the works of both the Canadian documentary dramatists and the Canadian poets strike close affinity regarding the technical strategies of exposing various realities of a given controversy, it seems pertinent here to touch upon such strategies. Frank Davey in "Counter textuality in Long Poem" remarks that the Canadian documentary poets utilized four artistic strategies viz. (i) external authority, (ii) metaphoric truth, (iii) assumption of multiple truths, and (iv) scientific standard of empirical verifiability on the basis of which the documentary poets have striven to reach and exhibit the truth of the issues they have chosen for their poems (33-34). It would also be noticed in the following chapters how the Canadian playwrights too have availed as per their requirements one or the fusion of more than one of the poetic strategies mentioned by Davey.

The Canadian playwrights, with their practice of unfolding all the possible perspectives on the pre-existing versions of the issues, seem to fall into the line of the Canadian poets who, as Davey suggests, also believed in "assuming multiple truths" of their subjects. To fracture the monolithic, colonial versions of the socalled Canadian myths and to discover new myths for them, when the Canadian playwrights like James Reaney, dedicatedly engaged themselves in the excavation of the archival records about their respective subjects, they were seeking "the external authority" of historical documents to support their dramatic 
arguments. The Canadian documentary playwrights have also created "metaphoric truth" by telescoping some historical incidents with the help of narrative strategies such as the use of chorus, voices, or other symbolic devices. To achieve that effect, in Riel, Joh Coulter prefers to amalgamate attributes of more than one historical figures into a single character. The fourth-scientific approach of the Canadian docu-poets as referred to by Davey was later followed closely by many Canadian playwrights.

Most often dramatists like Rex Deverell, Chris Brooks, Sharon Pollock, Reaney or Coulter preferred to instill a substantial documentary force into their works by availing screen projectors with which they could highlight realities of the issues being staged through photographs, newspaper clippings or maps. Several Canadian docudramatists used tape-recorded speeches and interviews of the real historic figures to strengthen the dramatic realities. Apt use of modern lighting also helps them project geographical locations and movements of characters in a precise manner.

This no-non-sense approach towards the issues being thematized assists the documentarians in convincing the techno-scientifically equipped modern mind sets of the audience, who need to be persuaded scientifically about the debatable issues with the help of actual documents and logic. With such documentary strategies the Canadian playwrights do succeed in creating authentic impressions of their individual perceptions about the issues they have taken up.

Considering the Canadian dramatists' preoccupation with the creation of genuine impressions of the works, Alan Filewood rightly regards the documentary theatre as "a genre of performance that presents actuality on stage and in the process authenticates that actuality" (qtd. in Jones 2).

To cope with the psychological needs of the modern audiences who could no longer be expected to be just bystanders of the dramatic re-presentations of the historical content, Canadian docu-playwrights exploit the anti-naturalistic theatrical style of presentation. Their dramatic patterns therefore often correspond with the critical, objective, detective, logical and interrogative attitudes of the post-modern 
dramatists/actors/ spectators. In creating an Alienation effect, they follow the objective of dramatic art as proposed by Bertolt Bretcht. This A-effect helps the artists/audience come out of their subjective selves by making them watch the reenactment of the historical events in a dispassionate manner.

In an article "Modern Theatre is an Epic Theatre:", Bretcht writes: "The modern theatre is an epic theatre" (847), according to which, in a Marxist fashion, theatre should be exploited as an instrument to objectively re-evaluate history. A-effect, in the Canadian documentary theatre also aims at "encouraging an attitude of critical detachment in the audience, rather than a passive submission to realistic illusion" (The Concise Oxford Dictionary of Literary Terms 4). To encourage the audience to watch their histories critically, the Canadian playwrights have created A-effect through introduction of Multiple Role Play, Intermittent Flashbacks, Agit-prop, Sudden Scene Changes and a Direct Audience-Actors-Communication.

In his documentary Collective entitled Buchans, Chris Brookes uses vast performance spaces, following the style of Richard Schener's Environmental theatre. This experimental method not only allows the artists to come out of the conventional boundaries of the proscenium stage, but also establishes a communion between the actors and the spectators.

What is important to note at this juncture is that so far as the questions of audience-actors communion, Role-play and A-effect are concerned, the so-called American/Canadian Experimental theatrical techniques seem to have been extension of the Elizabethan theatrical strategies, because as mentioned in an anonymous article that introduces Shakespeare's Tempest, during the Shakespearean era also the theatre used to be circular or octagonal and in those days also the simple stage property, absence of scenery, the role of women played by male actors, and the closeness between actors-audience had been the strategies that used to make the audience both physically and mentally submerge into the action of the play ("Elizabethan Theatre" 12-14).

For Shakespeare, such communion between the spectators and the theatre was necessary at first to fully entertain the mass, whereas in the Canadian 
docudramas such kind of communion is necessary for instructive purposes because their primary aim was to leave specific messages for the Canadian audience.

Along with the experimental devices, the playwrights have also used some of the traditional popular devices such as the play-within-the-play, ballads, games, mime and puppetry. They have utilized these devices for the exposition of historical realities and for satirizing the colonial attitudes towards the Canadian history.

It is also pertinent to note here that in spite of the preponderance of history, sociopolitical concerns and semi-propagandist stance of the Canadian documentaries, they cannot be classed with the conventional history plays, problem plays, commitment-plays, or even the American Living Newspaper from which the Canadian docudrama has inherited some theatrical techniques.

Therefore, considering the historical background of documentary experiments while Gregory Mason defines documentary theatre simply as a drama that "presents and re-enacts records from history," he takes care to add that "unlike traditional drama it [docudrama] is not founded on a freely imagined plot" (qtd. in Jones 2). The first half of Mason's definition equates the docudrama with a history play but the second half clearly mentions the dichotomy between the two. It can also be deduced from the descriptions of the English history plays and chronicles given in the Cole's notes (40-41) that a history playwright takes up his content from a remote past whereas according to Cuddon a docudramatist picks up his subject matter from a relatively "recent history" (100) since, unlike a history playwright, he is interested in scrutinizing the reliability of the sources from which he draws.

Discussing the basic difference between the process of writing a traditional history drama and a documentary play, Rex Deverell also writes in the playwright's Introduction to Medicare! that in the "...traditional historical drama... speech is invented to fit the history" but for writing his documentary Collective Medicare! he had "a plethora of rhetoric available, not only in manuscript but also on audio tape" 
(179). The former thus fictionalizes on the popular historical versions; the latter fictionalizes on non-fictional data which often challenges the popular versions.

A history playwright may write for the sake of exhibiting a myth to entertain his audience; whereas a Canadian documentary playwright designs his creation to illustrate a "precept," not a myth, as Dorothy Liversay notes, since a documentarian's basic aim is to instruct the audience ("Documentary Poem" 269).

A history playwright, in the conventional theatre of illusion, intends the audience to emotionally identify with the action when he glorifies the historical characters in order to appease his contemporary political/royal patrons. The docu-dramatist, on the contrary, as discussed before, in his anti-illusory theatre, attempts to "prevent the emotional identification of the audience" in the Bretchian style, as his objective is to depict controversial historical figures in an impartial light (M.H. Abrahams 47).

As a result, a documentarian's iconoclastic approach, as one finds in Reaney's trilogy, often displeases the contemporary political/social power structures instead of appeasing them. Therefore, as mentioned earlier, although both a history playwright and a docudramatist draw from history, they differ in certain aspects.

The Canadian docu-playwrights mentioned in this paper have of course taken some liberties with the process of presenting the historical data wherever it was necessary for them to carry out the artistic purposes and to frame the time schedule of the performances as one finds in Riel, for instance. In this regard, Dorothy Liversay's observation that a Canadian documentary poet employs "the actual data itself rearranged for the eye and ear" applies also to the docudramatist's methods of dealing with history (267).

It may also be noted that although a Canadian docudramatist also focus on sociocultural problems of their times, they cannot be equated with problem playwrights. Though both these genres relate social concerns, the difference between the two is that a problem playwright often generalizes a given social issues; whereas, a Canadian docu-dramatist particularizes it. In this regard, Michael Cook's Head, Guts and Soundbone Dance, David French's Of the Fields Lately or Sharon 
Pollock's Generations are Canadian problem plays because they throw a general focus upon the common social frictions that take place between the old and new generations of Canada; but Pollock's Komagata Maru Incident or Walsh are documentary expressions since they concentrate upon concrete events of the Canadian past.

In that context, although the Canadian docudramas such as Riel or Walsh discuss political problems, they cannot be equated either with the American Living Newspaper which was a dramatic form of "political propaganda" (Cuddon 367), or even with the 'committed' writers who were also "dedicated to the advocacy of certain beliefs.... which are political and ideological" (Cuddon 141). The reason why the Canadian docudrama defers from the other two is that a Canadian documentarian sounds more like a persuasive awakener rather than a staunch follower of any particular political ideology.

As one finds in Riel or in Walsh, the Canadian docudramatists expose the cruelties of the anonymous political power systems for the sake of creating a genuine sympathy for their protagonists, who had been victimized in the past by those political systems. The docu-playwrights thus criticize the political machineries not to ensconce any particular political ideology but to dramatically rehabilitate the controversial figures of history.

The use of history and its dry documents patterned in the docu-plays do raise a question regarding the possible dampening effects of history upon the creativity of the artist and the liveliness of the theatre. Therefore, when one examines the structures of the Canadian docudramas that incorporate history, socio-political concerns and instructive voices of the dramatists, one may encounter questions relating to the artistic merits of the form of the Canadian docudrama. But, despite the aforementioned problems just the reading of the plays assures the readers that the curious theatricalizm of the Canadian docu-plays and their anti-naturalism keeps the liveliness of the dramatic performance intact.

Like other forms of dramas, the form of docudrama should also be judged therefore from its artistic merits, and not form the view of historical accuracy alone, 
because even a considerable use of history does not disturb the artistry of this form of art.

While reading the Canadian docu-plays mentioned before, one cannot escape the feeling that it is the imaginative touches of the playwrights that enliven the bare bones of history. History is just a starting point for the Canadian documentarians which enables them to connect the audience with the theatre more smoothly and immediately. Reproduction of history is not the point for these playwrights because after all just an accurate reporting of a mishap does not make a play until the event is transformed by art into a very different category of imaginative experience. Referring to history is just a strategy for the artists to immediately capture the imagination of the audience. Once that is achieved, every documentarian in his own style skillfully begins to convince the audience as to why they must remodel some of the Canadian socio-cultural myths.

The unique features and imaginative potential of the genre of the Canadian documentary experiments which have been discussed here could also be of great help for any dramatist living in any part of the world, who wants to expose shortcomings of the myths about nationalistic pride and narratives of so-called progress by using the stage to interrogate the popular versions of history. 


\section{Works Cited}

Abrahams, M.H. ed. A Glossary of Literary Terms. 6th ed. Bangalore: Prison Books, 1993.

Baxi, Chandrakant. "Vatayan", Sandesh. (Saptahic Purti) 22 Oct. 2000: 1-8.

Bessai, Diane. "Documentary into Drama: Reaney's Donnelly Trilogy." Essays on Canadian Writing: James Reaney Issue. 24-25. (Winter-Spring/ 1982-83): 186-206.

Bolt, Carol. Buffalo Jump. Perkyns, Major Plays 384-442.

Brookes, Chris. dir. Buchans: A Mining Town. Canadian Drama / L'Art dramatique. 13. (Nov./Numero, 1, 1987): 72-115.

Bretcht, Bertolt. "Modern Theatre is an Epic Theatre." Dramatic Theatry and Criticism: Greeks to Grotowski. Ed. Bernard Dukore. New York: Holt Rinehart and Winston, 1974. 847-849.

Carson, Neil. "George Luscombe and the Theatre of Cabotin." Canadian Drama. 15.2 (1989): 149-168.

Cole's Dictionary of Literary Terms. Eds. Coles Editorial Board, New Delhi: Rama Brothers, 1991.

Concise Oxford Dictionary of Literary Terms. Ed. Chris Baldick. New York: OUP, 1990.

Coulter, John. "Riel." Perkyns 125-210.

Cudden, J.A. A Dictionary of Literary Terms. Delhi: Clarion Books, 1980.

Davey, Frank. "Counter-textuality in the Long Poem." Open Letter $6^{\text {th }}$ Ser. 2-3 (Summer/Fall 1985): 33-44.

Dickinson, Peter. "Documenting 'North' in Canadian Poetry and Music." Essays on Canadian Writing 59 (Fall 1996): 105-122.

"The Elizabethan Theatre." The Tempest by Shakespeare. 14-18.

Filewood, Alan. "The Political Dramaturgy of the Mummers Troupe." Canadian Drama/L'Art dramatique Canadian 13.1 (1987): 60-72.

Granatstein, J.L. Forward. Rubin, Canadian Theatre History 5.

Jones, Manina. "The Collage in Motion: Staging the Document in Reaney's Sticks and Stones." Canadian Drama 16.1 (1990): 1-22. 
Livesay, Dorothy. "The Documentary Poem: A Canadian Genre (1969)." Contexts of Canadian Criticism. Ed. Eli Mandel. Toronto and Buffalo: University of Toronto Press, 1971. 267-294.

Oxford Companion to Theatre Ed. Phyllis Hartroll. 4th Ed. New York: OUP, 1983.

Perkyns, Richard. ed. Major Plays of the Canadian Theatre. 1934-1984. Toronto Ontario: Irwin Publishing, 1984.

Reaney, James. The Donnellys. Victoria: Press Porcepic, 1983.

Rubin, Don. "Creeping Toward Culture: The Theatre in English Canada since 1945," pp. 318-331.

Ryga, George. The Ecstacy of Rita Joe. Vancouver: Talon Books, 1970.

Visweswara Rao, C.R. "Canadian Drama: Drama and the Social Milieu" Indian Journal of Canadian Studies VI (1997): 126-131.

Voaden, Herman. Hill Land. Perkyns, Major Plays 20-63.

\section{Mr. Nanavati Devang Sanatkumar Associate Professor in English SKUB Samiti Arts \& Smt. N. C.Zaveri Commerce College, Pipaliya Email: nanavati68@gmail.com}

